\title{
From Africa to Australia by train and plane
}

Welcome to the 98th issue of English Today and another eclectic look at developments in English around the world. We include three contributions from Africa - a useful reminder that some of the largest populations of English users live there. Rotimi Taiwo provides us with a guide to the changing role of English in Nigeria since early colonial times. He tells a story which is familiar elsewhere: how English was first used to communicate with the colonial rulers and then became a marker of status; how some regions of the country adopted English with greater enthusiasm than others; and how English eventually became the language of nationalism and agitation for independence. Such complex histories generate a complex pattern of usage in public and private contexts today. Bonaventure Sala describes Pidgin English in Cameroon (CPE) and how the development of written CPE is being held back by present 'chaotic' inconsistencies and variability in spelling. He suggests that CPE writing should follow English orthography where possible, deviating only where local pronunciation requires. Our third contribution from Africa is a brief linguistic survey of Zimbabwe, helping clarify the status of English there. Whilst English is one of the three official languages of Zimbabwe, it is so little used in rural areas that it might be considered a foreign language for a large proportion of the population. This perhaps explains why English, as used in Zimbabwe, includes both standard varieties which closely follow native-speaker norms, and localised varieties which can justifiably be called 'Zimbabwean English'.

Elsewhere, a group of graduate students from Northeastern Illinois University analyse the status of English in Malta, using a framework proposed by Edgar Schneider which explores the changing dynamic between native-speaker and local norms in postcolonial Englishes.

Our last issue included an article by Jin-Kyu Park on 'English Fever' in South Korea. Phyllis Chew continues the story of the desperate quest for English, by describing how thousands of 'study mothers' migrate to Singapore to help their children acquire English - often causing the break-up of family life as fathers and older children are left back home. Also in Singapore, Brian Poole puzzles over the use of the word 'alight' in public announcements to railway passengers.

Walter Seiler discusses the growing requirement for airline pilots to learn conversational English, in addition to the highly codified and limited phraseology of air traffic control. However, he argues that diversity in native-speaker varieties makes this problematical: 'English may have become the universally accepted language of aviation, but we are still a long way away from a universally agreed upon standard of English for aviation'.

The growth of English as a world language is often compared to that of Latin in medieval Europe, and almost as often with the implied warning that, just as Latin has all but disappeared from use, so the use of English will decline. Kanavillil Rajagopalan suggests the analogy with Latin is misleading and that the circumstances which caused the break-up of the hegemony of Latin do not apply to English today.

Native varieties of English are not ignored: Michael Bulley provides us with a short musing on the pronunciation of final ' $t$ ', whilst Joseph Sowa explores the use of 'as' in colloquial antipodean English.

Finally, Bertus Van Rooy provides us with a summary of IAWE14 - the fourteenth annual conference of the International Association for World Englishes, held in Hong Kong at the end of 2008.

The Editors

The editorial policy of English Today is to provide a focus or forum for all sorts of news and opinion from around the world. The points of view of individual writers are as a consequence their own, and do not reflect the opinion of the editorial board. In addition, wherever feasible, ET generally leaves unchanged the orthography (normally British or American) and the usage of individual contributors, although the editorial style of the journal itself is that of Cambridge University Press. 